\title{
A framework for estimating crime location choice based on awareness space
}

\author{
Sophie Curtis-Ham ${ }^{1 *} \mathbb{D}$, Wim Bernasco ${ }^{2,3}$, Oleg N. Medvedev ${ }^{1}$ and Devon Polaschek ${ }^{1}$
}

\begin{abstract}
This paper extends Crime Pattern Theory, proposing a theoretical framework which aims to explain how offenders' previous routine activity locations influence their future offence locations. The framework draws on studies of individual level crime location choice and location choice in non-criminal contexts, to identify attributes of prior activities associated with the selection of the location for future crime. We group these attributes into two proposed mechanisms: reliability and relevance. Offenders are more likely to commit crime where they have reliable knowledge that is relevant to the particular crime. The perceived reliability of offenders' knowledge about a potential crime location is affected by the frequency, recency and duration of their prior activities in that location. Relevance reflects knowledge of a potential crime location's crime opportunities and is affected by the type of behaviour, type of location and timing of prior activities in that location. We apply the framework to generate testable hypotheses to guide future studies of crime location choice and suggest directions for further theoretical and empirical work. Understanding crime location choice using this framework could also help inform policing investigations and crime prevention strategies.
\end{abstract}

Keywords: Awareness space, Crime location choice, Crime pattern theory, Rational choice theory, Routine activity nodes

The location of crime is not random; as we elaborate in this paper, offenders' decisions about where they commit crime follow predictable patterns, that reflect decisionmaking processes common to human spatial behaviour more generally. In the context of criminology, understanding these processes at the individual level enables predictions that can inform policing strategies: where might a given person offend next? Who is more likely to have committed crime in that location? Much has already been done to advance our understanding of these processes. Foundationally, Crime Pattern Theory explains that offenders commit crime where crime opportunities coincide with their 'awareness space' around 'activity nodes'; the places they learn to know during everyday

*Correspondence: SC398@students.waikato.ac.nz

${ }^{1}$ Institute of Security and Crime Science and School of Psychology, University of Waikato, Knighton Road, Hamilton 3240, New Zealand Full list of author information is available at the end of the article activities (Brantingham \& Brantingham, 1991, 1993). Further, a growing body of empirical research (discussed below) reveals that the associations between activity nodes and crime locations vary for different activity nodes. These variations hint at systematic mechanisms that mediate the relationship between activity nodes, opportunities, and crime. But these mechanisms have not yet been articulated in a coherent framework that explains how and when different activity nodes influence crime location choice. Drawing on both criminological scholarship and a broader literature in geography and psychology, this paper proposes a theoretical framework to systematise our current understanding and guide future research. The paper begins by setting the theoretical context of the framework. We then summarise the framework in a formal model and introduce its elements, before discussing the empirical support for each element in turn. The paper concludes by teasing out testable hypotheses for empirical exploration and suggesting further directions in which to expand the framework. 


\section{Context: awareness space, activity nodes and location choice}

Our framework is set in the context of Crime Pattern (CP) and Rational Choice explanations of crime location choice. CP theory holds that offenders commit crime where crime opportunities coincide with their awareness space around and between routine activity nodes, such as their homes, schools, workplaces, shopping and recreation locations (Brantingham \& Brantingham, 1991, 1993). Awareness space is, most literally, the places of which a person is aware ${ }^{1}$ and the related term 'activity space' refers to the subset of locations that people directly experience during their activities (Brown \& Moore, 1970; Horton \& Reynolds, 1971), consisting of activity nodes where people spend nontrivial amounts of time carrying out activities (Golledge, 1978; Golledge \& Stimson, 1997) and the paths (routes) between them.

Awareness space encompasses more than activity space. First, it includes the area normally within visual range of activity space. Second, awareness space exceeds activity space where it is generated from sources other than direct experience; for example, through word of mouth, news or other media (Brown \& Moore, 1970; Golledge \& Stimson, 1997; Horton \& Reynolds, 1971). When deciding where to carry out a future activity (i.e., making a location choice), we can either return to somewhere in our activity space, or explore somewhere new that is already in our awareness space from secondary sources, or of which we have no prior knowledge.

CP Theory views decisions about where to commit crime as products of individuals' activity and awareness spaces, and the structural backcloth of opportunities and environmental features that impact their attractiveness and accessibility (Brantingham \& Brantingham 1993; Brantingham et al. 2008). We supplement the former element of CP Theory in describing systematically the attributes of individuals' activity nodes which may make crime more or less likely in their vicinity.

Rational Choice (Clarke \& Cornish, 1985; Cornish \& Clarke, 1986) provides the psychological decision-making model on which our framework rests. It holds that the choice of crime location follows a rational decision-making process; the framework considers how prior activities contribute to that process. In the decision process, benefits, risks and costs associated with alternative locations

\footnotetext{
1 The terms 'action space' (Horton \& Reynolds, 1971; Wolpert, 1965), 'awareness space' (Brown \& Moore, 1970), 'mental map' (Gould, 1966, 1973; Gould \& White, 1986) and 'cognitive map' (Downs \& Stea, 1973; Tolman, 1948) are often used synonymously in this literature. Herein, only 'awareness space' is used for consistency with the environmental criminological literature. Similarly, the term 'activity node' or just 'node' is used in preference to the synonym 'anchor point' that also appears in the literature.
}

inform a calculation of their usefulness for a given activity; locations with high perceived utility are more likely to be chosen. ${ }^{2}$ These decisions are not necessarily objectively optimal; offenders' knowledge of the alternatives is incomplete, limited to their awareness space. And, as our framework details, offenders' judgments of locations' crime utility are affected by the extent and nature of their knowledge of these locations, based on their prior activities at them and indirect information sources.

\section{A model of activity node influence on crime location choice}

Within this theoretical context, we focus on how knowledge of locations generated by previous activities shapes the decision about where to commit crime. To a lesser extent, we discuss the role of awareness space derived from indirect sources, and exploratory behaviour. In this section we briefly introduce the framework, before elaborating on its elements in their own respective sections. From the crime location choice literature, we identify a range of factors associated with people's prior activities that predict their subsequent offending in the same locations as, or near to, those activities. We group these factors into two clusters, reflecting quantitative attributes of prior activities in a place (e.g., their frequency), and the quality or nature of those activities (e.g., what the activity was). These groupings lead us to suggest two mechanisms through which prior activities influence (crime) location choice. First, the frequency, recency, and duration of prior activities affect how well a location is known, and thus how much the knowledge of that location can be relied on in calculating (crime) utility. Second, the nature of those activities affects what is known about a location, and the type of activities it affords. Further, the more similar the prior activity to the activity involved in the current choice scenario, the more likely it is to have generated knowledge suggesting the location's usefulness for the activity. We attach the terms 'reliability' and 'relevance' to describe the two mechanisms: offenders are more likely to commit crime where they have knowledge that is both reliable and relevant to the particular crime.

Although we provide more detailed explanation of these concepts below, a concrete example may help at this point to illustrate the distinction, and interaction,

\footnotetext{
${ }^{2}$ We use the term utility as defined in the descriptive and predictive (as opposed to normative) version of expected utility theory. Expected utility theory describes and predicts how people make choices in situations where they are uncertain about the outcomes of their actions (Lattimore \& Witte 1986). Their uncertainty is a function of information constraints. In the case of the decision where to commit an offense, offenders can only be aware of a subset of all potential offense locations and can have only limited information on their characteristics, and thus on the possible benefits and costs of offending in each of these locations.
} 


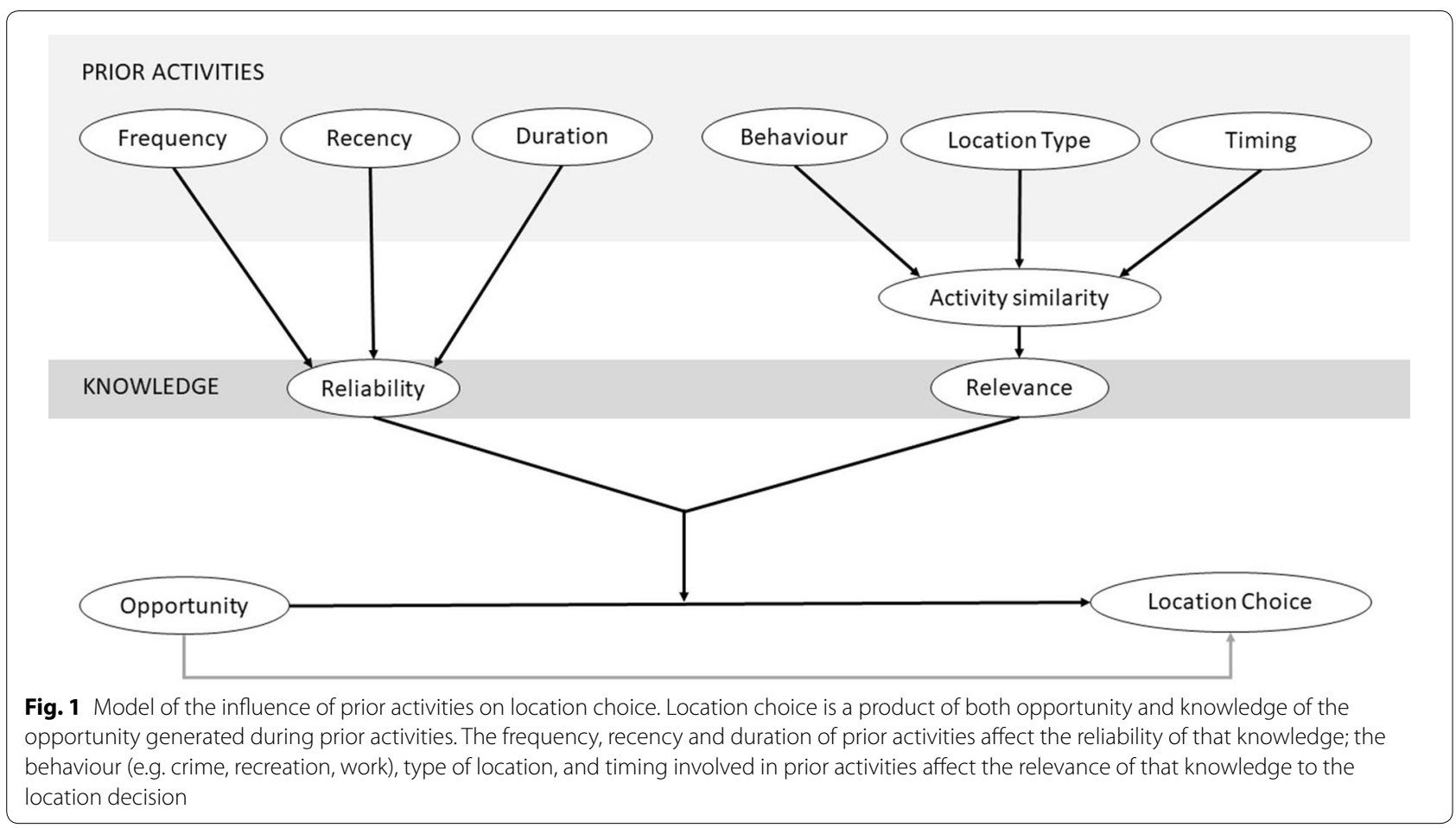

between the two mechanisms. A burglar might have a high level of familiarity with a neighbourhood, A, built up over many previous visits to relatives who live in the area. They have reliable knowledge of the location, but not having committed a burglary there before, they do not have specific knowledge of its potential for burglary. Neighbourhood A has high reliability but low relevance. Neighbourhood B, in contrast, the burglar has only visited once, and committed a burglary on that occasion. It definitely has burglary potential, but they might have just been lucky; the burglar does not know it well enough to be confident returning. Neighbourhood B has high relevance but low reliability. Neighbourhood $C$ is just as familiar as neighbourhood $\mathrm{A}$, as the burglar lived there until recently, and they have committed burglaries there in the past. Knowing it well, and knowing from direct experience that it has attractive burglary opportunities, the burglar more likely considers neighbourhood $\mathrm{C}$ more of a sure thing, and therefore the better option. Neighbourhood $C$ has high reliability and high relevance. Neighbourhood D, which has abundant opportunities but lies outside of awareness space, is not considered. The offender has no reliable or relevant knowledge of Neighbourhood D.

Figure 1 summarises the framework in a formal model illustrating the theorised pathways from attributes of prior activities to crime location choice. In the model, knowledge generated by prior activities moderates the relationship between crime opportunities and location choice; opportunity is a necessary condition for a location to be chosen but is not sufficient, because offenders need to have knowledge of the opportunity (Brantingham \& Brantingham, 1991). Opportunity is also directly linked to location choice in the model (grey line in Fig. 1), to reflect that people sometimes choose to explore new locations rather than exploit previously visited ones. It captures situations where crime occurs outside of offenders' existing activity space, either as a result of indirect sources of awareness, or exploratory behaviour. Since our focus is on the role of offenders' prior activities in generating awareness of criminal opportunities, the framework does not elaborate on what makes situations crime opportunities. For the purposes of our model, the paths between activity nodes are also locations in which people have previously conducted activities (travel between activity nodes) and their influence on crime location choice is affected by the same factors.

We suggest these factors predict the likelihood that an offender will return to a given activity location and commit an offence, whether that offence is planned or opportunistic (see Brantingham \& Brantingham, 2012; Cromwell et al., 1990; Elffers, 2004 for discussions of such 'target search' typologies). Planned offences typically involve first a decision of whether to offend, then where. Knowledge of prior activity nodes informs the assessment of where. Offences committed opportunistically 
or provoked spontaneously generally involve a decision whether to offend, given a current location. The likelihood of an offender being at that location, at that time, and identifying the crime opportunity, is also a product of their previous activities there, and knowledge generated by those activities will inform the assessment of the risks and rewards associated with the offence. The more reliable and relevant that knowledge, the more likely a future crime opportunity will be identified and acted on.

The next two sections review the empirical literature which underpinned the development of the reliability and relevance pathways in the framework, drawing on crime-specific research supplemented with research in non-criminal domains. The crime specific evidence comes primarily from a series of studies using Discrete Spatial Choice Models (DSCMs), a form of Discrete Choice Model. Discrete Choice Models apply a form of logistic regression to decision-makers' choices from a set of alternatives, to identify the attributes of alternatives that are associated with increased likelihood of being chosen (Ben-Akiva \& Lerman 1985; McFadden, 1984). Non-spatial discrete choices can include such decisions as between cereal brands (e.g., Nevo, 2001), travel modes (e.g., Nguyen et al., 2017) or service providers (e.g., Ida and Kuroda, 2006). In DSCMs the choice set contains alternative locations where the decision-maker can choose to carry out an activity; for example, commit a crime (Ruiter, 2017), shop (e.g., Hillier et al., 2017), or move residence (e.g., Ben-Akiva \& Bowman, 2016). In crime location choice, DSCMs calculate the relative probability of a location being selected for offending based on its proximity to a given activity node, controlling for proximity to other activity nodes and other features of the location (Ruiter, 2017).

\section{Reliability factors}

Three quantitative attributes of prior activity nodes have strong empirical support for their association with crime location choice and are thus included in the framework under the 'reliability' pathway. Frequency (how often) refers to the number of visits per time period (e.g., "daily", "twice a week" or "four times per year"). Recency refers to amount of time elapsed since the last visit (e.g., "since yesterday" versus "since last month"). Duration refers to the length of a period during which the individual has been visiting an activity node (e.g., "for three months" versus "for five years"), as opposed to the average length of time spent per visit. ${ }^{3}$

\footnotetext{
${ }^{3}$ We note average visit duration as an additional potential activity attribute but choose to focus on those attributes that have more empirical evidence relative to crime location choice. Future research could explore its contribution to the model.
}

No DSCM study to date has examined frequency, recency and duration of activity nodes simultaneously to separate out their individual and combined contributions. Considering all activity nodes (home, others' homes, school/work and leisure) combined, Menting, Lammers, Ruiter and Bernasco (2020) and Bernasco (2019) found that offences were more likely to occur near activity nodes that were visited more frequently. Further, the more recently and longer that offenders have resided at an address, the more likely they are to offend nearby, with recency and duration producing an additive effect (e.g., Bernasco, 2010; Bernasco \& Kooistra, 2010; Menting et al., 2016). The same pattern holds for close family members' homes and recency of residence (Menting et al., 2016). There are similar findings for both the number (frequency) and recency of prior crimes (Bernasco et al., 2015; Lammers et al., 2015; Long et al., 2018).

Studies revealing differences between different types of activity node are also informative. All other things being equal, we would expect activity nodes that are typically visited more frequently, recently or over longer periods to have higher odds of crime occurrence nearby than other activity nodes. In line with this expectation, the odds of crimes being committed near offenders' home nodes are consistently higher than near their family members' home nodes (Menting, 2018; Menting et al., 2016). Further, more offences occur along the home-work path than other paths: this path being the most well-trodden (Rengert \& Wasilchick, 1985; Ruiter \& Davies, 2018).

The roles of frequency, recency and duration in crime location choice are reflective of their roles in location choice in general. The more often people have visited a location, the more likely they are to return (Pappalardo et al. 2015), even if similar opportunities exist closer to home (Hannes et al.. 2008). The compounding effect of frequency is also evident from the habitual, automated nature of day to day travel choices (Gärling \& Axhausen. 2003; Hannes et al., 2009). Recency increases the odds of choosing a location, whether frequently visited previously or not (Alessandretti et al., 2018; Barbosa et al., 2015). These patterns have been confirmed across a range of countries and geographic scales (Yan et al., 2017). Further, incorporating activity nodes that have been in awareness space for a longer time, but are less frequently visited, improves predictions of future location choice (Song et al., 2010).

We suggest that frequency, recency and duration operate on location choice insofar as they affect how well we know locations and thus how much we can rely on that knowledge making a location decision. In short, the more often, recently, or longer we have visited a location, the more reliable our knowledge of it. Reliability, as we use the term, refers to perceived or subjective reliability, 
because one can be wrong about the accuracy of one's knowledge about a location, leading to over-reliance on inaccurate knowledge or under-reliance on accurate knowledge. ${ }^{4}$ This perception, however, may be unconscious. Spatial decisions are frequently habitual or automatic and not experienced as conscious deliberations, with assessments of reliability thus informing these decisions implicitly (Downs \& Stea, 1973; Hannes et al., 2006, 2008, 2009).

Evidence from interviews designed to elicit offenders' implicit (or explicit) decision-making process highlights the importance of having reliable knowledge of potential crime locations. Rengert and Wasilchick's (1985) seminal research found that US burglars favour familiar areas, tending to extend out from those familiar areas when searching for crime opportunities. In two more recent studies, burglary and prolific property offenders in the US and UK respectively were asked to rate their level of familiarity with areas on a map, along with how likely they were to offend in each area (Rengert \& Wasilchick, 2000) or which areas were the best (to worst) for them to offend in (Summers et al., 2010). Both studies found large overlaps between locations rated as more familiar and more likely or attractive for offending (see similarly, Costello \& Wiles 2001; Wiles \& Costello 2008). The importance of knowing an area well, through either noncriminal activities or through multiple reconnaissance visits before offending is also evident from offenders' narrative accounts reported by Summers et al. (2010, pp. 266-267):

"...you tend to stick to the areas that you know well. (Offender RP07).

... you want to know the best routes to get out quick, and, you know, so you trawled it for a couple of days and then you'll go back... (Offender RCO2)."

There is also more general evidence that frequency, recency and duration affect the reliability of people's location knowledge, supporting our proposed mechanism. For example, Golledge (1978) compared people's self-assessed familiarity with different areas, judgments of the relative spatial layout of various locations within those areas, and the actual spatial layout of those locations. Both familiarity (i.e., perceived reliability) and accuracy of spatial judgments were highly correlated with how long participants had resided in an area. Likewise,

\footnotetext{
${ }^{4}$ For example, information processing errors can occur during encoding, storage and retrieval of information about the environment (Chorus \& Timmermans, 2010; Golledge, 1999; Golledge \& Stimson, 1997; Lloyd \& Cammack, 1996; Mark et al., 1999). But, as decades of research on heuristics and biases have shown, people are often not aware of the fallibilities produced during information processing (Kahneman, 2003).
}

accuracy of spatial knowledge is higher for locations which have been visited before, and home nodes of longer duration (Spector, 1977 cited in Golledge, 1978). More recent studies confirm positive relationships between self-reported familiarity with areas and both duration and recency of exposure to the area, and with proximity to high frequency activity nodes such as home, work, and commercial areas (Zhang et al., 2016, 2019). Both self-assessed way-finding ability and accuracy of spatial knowledge are also positively related to length of residence in a location and the number of trips to a location per week (Chorus \& Timmermans, 2010). ${ }^{5}$ Consistent with our model, therefore, more frequent, recent and enduring activity nodes produce more accurate knowledge that is, generally, more likely to be assessed as reliable to inform future location choices.

\section{Relevance factors}

We find empirical support for three qualitative attributes of prior activity nodes that appear to affect crime location choice. We can think about prior activities in terms of the behaviour involved (e.g., criminal vs non-criminal, or the specific type of crime), the type of location involved (e.g., residential vs commercial), and their timing (e.g., time of day, day of week). The more similar a prior activity is in any of these respects to the activity involved in the location choice, the more likely we are to choose to return to that location.

The clearest example, where crime location choice is concerned, is prior crime. Prior crimes potentially constitute the closest degree of similarity, behaviourally, between a prior activity in a location and a future choice scenario, thereby providing the most relevant knowledge of the location's crime opportunities. Correspondingly, prior crime nodes are generally more likely to be chosen than home or family home nodes (e.g., Frith, 2019; Menting et al. 2016; Vandeviver \& Bernasco, 2019) and other non-home nodes (Bernasco 2019). ${ }^{6}$ The odds are even higher if the prior crime is of the same broad crime

\footnotetext{
${ }^{5}$ Interestingly, the average duration of individual trips to a location, although predictive of accuracy, was not related to self-assessed spatial knowledge. Individual trip duration is distinguished from our concept of duration (total length of a person's association with a given node); see note 3 above.

${ }^{6}$ One exception is when violent offences are considered separately, in which case the odds are higher at home or family home nodes (Menting, 2018). In our model's terms, the family violence offences within this category would involve similarity in activity between the past family dynamics in a home location, and the future situation giving rise to the violence. If family related violence offences were removed, we predict that home nodes would become less influential relative to prior crime nodes, in line with the pattern for property and other crimes that are less likely to involve family members.
} 
category as the future crime (van Sleeuwen et al., 2018). ${ }^{7}$ Future studies could leverage research into the similarity between specific crime types (Kuang et al., 2017) in exploring the relationship between crime behaviour similarity and crime location choice.

There is also evidence that although prior crime success increases the likelihood of returning to its location for future crime, negative outcomes of prior crimes are not a lasting deterrent to returning to their location. Long et al., (2018) found that offenders were less likely to commit a robbery in the same location as a prior robbery they were arrested in the act of, than if they (initially) got away with it. However, they were still more likely to offend in a prior crime location where they were arrested, than a non-prior crime location. The observation that often crime returns to previous levels following the deterrent effects of police presence (Banerjee et al., 2019; Sorg et al., 2013), further suggests that offenders return to prior crime locations once they believe 'the coast is clear'.

We can also look outside prior criminal behaviour to a range of prior activities that could be more or less similar to any given crime activity. For example, youth 'hangout' nodes could be seen as a step removed from prior crime nodes in terms of the behavioural similarity of prior and future activities. Studies using space-time budget surveys to collect data on the locations and contexts of young offenders routine and delinquent activities have found that they are more likely to offend at or near hangout locations which involve unsupervised and unstructured peer-group activities, even compared to higher frequency nodes such as school and home (Bernasco et al., 2013; Miller, 2013; Wikström et al., 2010; see also Bichler et al., 2012). Further, the odds of young offenders committing crime near any activity node are almost four times greater than the odds near home nodes alone (Menting et al., 2020). 'Hangout' activities are more likely to involve delinquent and boundary pushing behaviour with greater similarity to criminal activity than activities in constrained settings; they are also more likely to involve crime attracting/generating location types

\footnotetext{
${ }^{7}$ Here the discrete choice research converges with literature on the near repeat phenomenon (e.g., Bernasco, 2008; Johnson et al., 2009) and crime linkage (e.g., Tonkin et al., 2011, 2012), which confirms that offences that are close in space and time are more likely to have been committed by the same offender. This pattern is often explained in terms of a 'boost' mechanism, whereby successful crime commission causes a follow-up crime by motivating the offender to return to the same location, and a 'flag' mechanism, whereby repeated offending at the same location (possibly but not necessarily by the same offenders) is merely a symptom indicating that the location continuously provides criminal opportunities (Johnson et al., 2009; Lantz \& Ruback, 2017; Pease, 1998). These explanations are consistent with our model: the boost effect is causal, and a product of offenders' highly recent (reliable) and relevant (prior crime) knowledge; the flag mechanism is only a product of opportunity.
}

such as malls, entertainment facilities and other commercial hubs (Bichler et al., 2014). In a similar vein, interviews with drug dependent residential burglars revealed that their offences tended to cluster around places they purchased drugs (Rengert, 1996). Reconnaissance activities, where offenders seek to develop knowledge of crime opportunities to which they can later return (Rengert \& Wasilchick 1985; Summers et al., 2010; van Daele et al., 2012), are a further example of prior activities that could be considered behaviourally similar to the crime itself by comparison to other routine activities.

Identifying the types of prior non-criminal activities that are associated with crime location choice, based on the similarity between particular non-criminal behaviours and specific crimes, requires further investigation. We speculate, for example, that locations where a person has been involved in a crime as a victim or witness may be 'similar' in the sense of involving the same crime, but in a different role. For example, a teenager witnessing a friend shoplift may return to that shop if later motivated to shoplift.

Turning to location type, at the aggregate level it is wellestablished that different types of crime are correlated with different types of location, at scales ranging from specific premises such as bars and shops to areal level land use (e.g., Tillyer \& Walter, 2019; Weisburd et al., 2016). Isolating the influence of prior activities in different types of location therefore requires studying specific crime types separately. The only DSCM study comparing activity node influence across specific crime types ${ }^{8}$ found that residential nodes (current and prior homes) had a stronger relationship with location choice for residential burglary than for thefts of cars and robbery (Bernasco, 2010). ${ }^{9}$ Similarly, offenders tend to travel farther (on average) to commit commercially than residentially focused crimes, suggesting lower home node influence in commercial crime location choices (Ackerman \& Rossmo 2015; Townsley, 2016). These results support the suggestion that offenders are more likely to offend near activity nodes of the same location type (residential versus commercial) as that targeted by the offence. Locations can also be similar in terms of their social rather than built

\footnotetext{
${ }^{8}$ Other DSCM studies either use aggregate groupings (e.g., all felonies, all violence, all property offences, or combining residential and commercial burglary) which mask variation between more specific crimes; or they focus on one crime (predominantly residential burglary), with cross-crime comparisons confounded by cross-study differences in jurisdiction, nodes and other co-variates included, and modelling methods.

9 Assaults had an even stronger association with home and prior homes, likely due to the inclusion, and prevalence, of domestic violence (see also Menting, 2018). Combining domestic and other violence is likely to have masked differences that our model predicts, due to their typical settings (home/public places).
} 
features, such as the degree of place management or guardianship (Felson, 2008). Similarity in these respects may also be salient to crime location choice: offenders would be more likely to return to places with similar social environments to those which facilitate a particular crime.

Similarity of prior activity timing also matters in crime location choice, at least for prior crimes. Offenders were approximately 46 times more likely to choose a location where they previously committed a crime of the same type, on the same weekend day, at the same hour of the day, than a location with no prior crime (26 times for weekdays; van Sleeuwen et al., 2018). These odds decayed steeply with decreasing timing similarity (e.g., within 2 , $3 \mathrm{~h}$, and so on, and different weekend or weekdays).

The pattern of returning to locations where prior activities match the current intended activity is seen in studies of non-criminal spatial behaviour. Most of people's activities occur in a small set of locations that are visited recurrently for the same purpose, at the same time of day, using the same transport mode (Hanson \& Huff, 1988). A prior visit to a shopping location is a far larger predictor of future shopping location choice than the mere presence of shopping opportunities in a location (Sivakumar \& Bhat, 2007; see also Arentze et al., 2008).

We suggest that prior activity similarity operates on location choice insofar as it reflects whether prior activities have generated knowledge that is relevant to the activity involved in the location choice. The more similar a prior activity is to the activity involved in a future choice, the more likely the prior activity is to generate knowledge of its location's utility that is generalisable to the future activity (i.e., more relevant knowledge). To use the language of CP Theory, similar prior activities are more likely to generate knowledge that matches an offender's mental template of a 'good' opportunity for future crime (P. L. Brantingham and Brantingham 1993). The generalisability of learning from past to future activities is a product of their similarity; broadly speaking, the more similar two situations or stimuli are, the more likely we are to generalise knowledge of one to the other (Gentner \& Medina, 1998; Howard, 2000; Tenenbaum \& Griffiths, 2001). To give a simple example, in determining where to dine out, we think first of places we have dined before, not the places we have purchased groceries; our knowledge from previous dining experiences is more relevant to future restaurant choices. Relevance, in our usage, refers to how much the knowledge of a location favours its usefulness for a given activity. In contrast to lay definitions of 'relevance', we use the word to indicate knowledge of good opportunities; knowledge of a lack of opportunities is less relevant knowledge. In the dining example, a restaurant where we previously experienced poor service would have less relevance to our decision than one where we previously experienced excellent service.

Relevant knowledge acquisition requires both the presence of opportunities and the generation of awareness of them through prior activities. The presence of crime opportunities can, to an extent, indicate an awareness of them (relevant knowledge). For example, considering the interaction of opportunity and home node proximity, Menting (2018) found that the odds of crime near home nodes were lower when there were fewer bars, restaurants and hotels-premises which can act as crime generators or attractors (Brantingham \& Brantingham, 1995) - in the vicinity. Further, interview studies confirm that prior non-criminal activities can generate knowledge of crime opportunities (e.g., Clare, 2011; Cromwell et al., 1990; Wiles \& Costello, 2008). For example, some burglars identify suitable neighbourhoods, or specific targets, through employment or social activities (Wright \& Decker, 1994). But to our knowledge, no study has yet explicitly explored the link between prior activity similarity and offenders' knowledge of locations' opportunities for particular crimes. ${ }^{10}$

We can, however, interpret the studies discussed above linking activity similarity to location choice, in terms of how similarity of behaviour, location and timing generates relevant knowledge. Prior crimes naturally generate highly relevant knowledge applicable to decisions about where to commit future crimes, particularly if they involve the same crime. We also saw that experience of disutility (through arrest, or increased risk of arrest) leads to reduced odds of location choice, by comparison with successful offences. Consistent with our restaurant example, this negative experience produces knowledge that is less well matched to the ideal template for the crime, and thus less relevant than had the crime succeeded. But because the prior unsuccessful crime behaviour is more similar (to future crime) than prior non-criminal behaviour, the knowledge gained from unsuccessful prior crimes may still be more relevant than that gained during non-criminal activities, as reflected in the preference for prior unsuccessful crime locations over locations with no prior crimes (Long et al., 2018).

In terms of location type, locations are typically designed with specific uses (behaviours) in mind, so if the location type is the same, so is the behaviour. Exceptions exist when locations are designed for multiple purposes

\footnotetext{
${ }^{10}$ Several studies have quantified offenders' crime-relevant knowledge by asking them to rate how attractive locations are for a given crime, or how likely it is they would offend there (Rengert \& Wasilchick, 2000; Summers et al., 2010) but did not compare these measures with the kind of activities carried out in those locations.
} 
or when they afford activities, such as crime, for which they were not intended. Thus, knowledge of shops visited previously for legitimate purposes will be more relevant to a decision about where to shoplift than, say, a home or workplace node, despite the different behaviour involved in the activities (shopping/shoplifting). And knowledge of a residential area gained during prior house burglaries will be less relevant to a decision about where to burgle a commercial property, despite the behaviour (burglary) being similar. The greater association of residential nodes with residential burglary location choice (Bernasco, 2010), and apparent lesser influence of home nodes on crimes for which commercial areas present more opportunities (Ackerman \& Rossmo, 2015; Bernasco, 2010; Townsley, 2016), is consistent with the role of location similarity in generating relevant knowledge.

Lastly, if the timing of previous exposure to a location does not match the timing of its opportunities for a given activity, we are less likely to identify those opportunities and thus gain relevant knowledge. For example, having only visited a shopping precinct during the day, we would be less aware of its nightlife affordances. Likewise, a prior burglary committed overnight provides knowledge of the location's overnight burglary opportunities, and less information of relevance to its daytime utility. The burglar is more likely to choose that location for a subsequent overnight burglary, than a subsequent daytime burglary (as seen in van Sleeuwen et al., 2018). Additionally, as argued by Ratcliffe (2006), paths connecting to the home node are traversed with greater temporal variability than other paths, generating greater exposure to differently timed opportunities. Home nodes are thus more likely to generate relevant knowledge of nearby crime opportunities than nodes visited only at particular times or on particular days, potentially explaining why even locations near home with few crime opportunities are more likely to be chosen than locations further afield with more crime opportunities (Menting, 2018). ${ }^{11}$ However, there are exceptions to the tendency to return to prior activity nodes, which we now consider.

\section{Crime location choice outside of activity space}

With increasing distance from prior activity locations, activity space transitions to awareness-only space, then to exploratory, unknown space. Absent direct measurement of awareness space, we do not know where these lines are drawn, and thus which crimes fall into each space. ${ }^{12}$ But we do know that crimes are most likely to

\footnotetext{
11 The high reliability of knowledge around home nodes also likely contributes to this finding.

12 Most studies estimate awareness space from activity locations, rather than measuring it directly. See Summers et al. (2010) for a rare exception, where offenders' awareness space was directly measured via ratings of familiarity.
}

occur in the immediate vicinity of prior activity nodes, and that this likelihood declines with distance from these activity nodes (Bernasco, 2019; Menting et al., 2020) and their connecting paths (Reid et al., 2014; Rengert \& Wasilchick, 1985; Ruiter \& Davies, 2018), as the likelihood of being in exploratory space increases. Crime in novel locations is, therefore, a novelty.

As Bernasco (2018) points out, this 'distance decay' pattern for crime reflects non-criminal spatial behaviour patterns. Most people exhibit a predominant pattern of returning rather than exploring, basing their activities around a few highly frequented nodes (Alessandretti et al., 2018; González et al., 2008; Pappalardo et al., 2015) and displaying distance decay, with new activity nodes chosen with decreasing frequency at increasing distances from existing activity nodes (Hasan et al., 2013; Kang et al., 2012; Sivakumar and Bhat, 2007).

In our framework, distance decay in location choice probability could reflect distance decay in the reliability and relevance of location knowledge. The closer a location is to a prior activity location, the more likely we are to have reliable knowledge of it, having been exactly at, near or passed through it en route. Further, applying Tobler's first law of geography (Tobler, 1970), whereby the similarity of locations increases the closer they are to each other, the closer a location is to a prior activity location, the more likely it is to afford the same opportunities and involve the same risks, and thus to generate relevant knowledge. Correspondingly, empirical research confirms that the closer it is to a node, the more likely a location is to be in self-reported awareness space (Horton and Reynolds, 1971; Zhang et al., 2019). But on those occasions where offending occurs away from activity space, what drives location choice?

Co-offending generates awareness of crime opportunities away from an offender's activity space through the sharing of knowledge between current or prior cooffenders. DSCM studies confirm the former: crimes committed in groups are more likely to occur near at least one of the current co-offenders' present or past homes (Bernasco, 2006; Lammers, 2018) or prior crimes (Lammers, 2018; Vandeviver \& Bernasco, 2019) than at locations in no group member's activity space. Confirming the latter, Lantz and Ruback (2017) found that repeat burglaries of the same property were more likely to be committed by a previous co-offender of the initial offender, than by a burglar with no co-offending connection.

These co-offending effects exemplify the influence of location knowledge generated through social networks in general. Toole et al. (2015) demonstrated using cell phone data that when people travelled to locations they had not 
previously visited (during the data collection period), their novel destinations could be predicted from the locations frequented by their social contacts (connected via their phone calls).

Exploration outside existing awareness space to commit crime is also evident. ${ }^{13}$ Offenders may deliberately seek to expand their awareness space, venturing away from familiar locations in search of offending opportunities (Brantingham and Brantingham, 1991, 1993; Rengert \& Wasilchick, 1985). Offenders new to a city or country may engage in exploratory behaviour prompted by a lack of opportunities within their limited awareness space (van Daele \& Vander Beken, 2011). Conversely, exploration might occur as a product of confidence associated with criminal expertise (Clare, 2011; Nee, 2015) or of the need to 'forage' for criminal opportunities elsewhere when prior crimes have resulted in depleted opportunities or increased risk of capture (Johnson et al., 2009; Johnson \& Bowers 2004). Opportunistic offences that occur 'on the spur of the moment' in the context of noncriminal activities in places not previously visited will also appear exploratory.

Criminal exploration driven by a lack of opportunity knowledge is consistent with general human mobility patterns: people explore more when they have fewer return-worthy nodes in their activity space, and less as the number of nodes in their activity space grows (Pappalardo et al., 2015). Further, where people explore can be predicted from the popularity of a location amongst the population (Hasan et al., 2013; Pappalardo et al., 2015; Wang et al., 2019), suggesting the potential to predict individual offenders' crime locations in exploratory space from locations' aggregate popularity amongst offenders (i.e., where similar crimes concentrate).

Examining the circumstances when offenders' location choices-based on secondary sources, or deliberate exploration-cannot be predicted from prior activity nodes presents an opportunity for further theoretical development. In the final section, we highlight some additional avenues for both empirical and theoretical exploration.

\footnotetext{
${ }^{13}$ Long home-crime distances do not necessarily imply exploration outside awareness space. Evidence of long distances between offenders' homes and their crimes from 'Journey to Crime' studies (as summarised in Ackerman \& Rossmo, 2015; and Xiao et al., 2018 for example), or of offenders who 'commute' from homes located outside of the area in which they offend (Canter \& Larkin, 2008), is uninformative on this point, insofar as it fails to account for the presence of other activity nodes (see for example, Wiles \& Costello, 2008).
}

\section{Future research directions}

To help guide future crime location choice studies, we apply the framework to generate some examples of new (or newly framed) predictions as to the relative influence of individual nodes and of different activity node types (home, work, etc.), thus demonstrating its fertility (Ward et al., 2005). We also make other suggestions for future research and research methods. Turning first to the hypotheses, research testing these could measure reliability and relevance through offenders' self-report (e.g., ratings of familiarity and locations' crime utility) or use the attributes of prior activities (frequency, recency, duration and activity similarity) as proxies.

H1: Nodes (and paths) with high reliability and relevance (regardless of what type of node they are) will have stronger associations with crime location choice than those lower on either or both of these dimensions.

H2: Given the likely abundance of residential targets around residential nodes, residential nodes (i.e., the homes of offenders and their family/friends), through a combination of high reliability and high relevance, will have a stronger association with crime location choice for crimes targeting residential properties, than for non-residential crimes.

H3: For crimes targeting or typically occurring near commercial properties, nodes such as work and recreation that tend to be in commercial areas will have a stronger association with crime location choice than residential nodes.

H4: The degree of association between prior crime nodes and crime location choice will reflect the similarity between the prior and future crime. For example, the location of a prior domestic assault is unlikely to have much bearing on where an offender will shoplift; a prior theft location will be more predictive; a prior shoplifting location even more so.

H5: The more reliable and relevant nodes offenders have, the less likely they will be to offend in places they have not been before.

H6 Offences occurring outside of activity space are more likely to occur near co-offenders' and other associates' activity nodes, or where similar crimes concentrate.

Opportunities for further theoretical development arise from several limitations worth mentioning. First, completeness: we focused on activity attributes explored in previous literature, which may simply represent those 
that are more easily measured. There is opportunity to expand the framework to identify, and quantify, additional activity attributes and variables which moderate the effects of reliability and relevance. As noted, other environmental and individual factors impact the processing of spatial information and thus reliability. Additionally, variation in offenders' ability to generalise past activities to future crime is likely, given differences between novice and expert offenders' recognition of cues to target attractiveness (Clare. 2011; Nee. 2015; Nee and Meenaghan. 2006) and variation in learning generalisation more generally (McDaniel et al.. 2014). Several DSCM studies have found individual differences in the extent to which prior activity nodes are associated with location choice (Frith. 2019; Frith et al.. 2017; Townsley et al.. 2016), which may reflect individual differences in the acquisition of reliable and relevant knowledge or in reliability/relevance preference thresholds.

Further elaborative work might also formulate how steeply the probability of crime location choice declines with distance for different nodes. The shape of the distance decay function is typically non-linear for the home node (Bichler et al., 2011; Hammond \& Youngs, 2011; Smith et al., 2009), but just as the peak height of this curve (i.e., probability of location choice) varies between nodes, so may its gradient (as demonstrated by Brantingham and Tita, 2008 in a simulation study). Likewise, future work might explore whether, and when, a 'buffer zone' of reduced crime probability, as sometimes appears in the immediate vicinity of home nodes (Bernasco \& Dijke 2020), appears around non-home nodes. ${ }^{14}$

A final theoretical avenue to highlight relates to crime location choice outside of activity space. For example, how do indirect sources such as online maps and other location information aid the identification of criminal opportunities? ${ }^{15}$

Lastly, on a methodological note, future empirical research should corroborate the findings on which the framework was based, using a wider range of measurement and modelling methods. DSCM studies to date

\footnotetext{
${ }^{14}$ Buffer zones may appear where offenders need to minimize the risk of recognition by victims or witnesses (Rossmo, 2000) but can also reflect a lack of crime opportunities or specific target search patterns. In the former case, there could be a threshold at which high frequency nodes become less relevant due to the higher risk of identification, suggesting the location's disutility for offending. We also note that buffer effects appear when considering the frequency of travel to non-criminal activity nodes at different distances from home (Bichler et al., 2010). However, we suggest a buffer zone would be unlikely for prior crime nodes, given that near-repeat offences against neighbouring targets are often committed by the same offender (Bernasco, 2008; Johnson et al., 2009)

15 Evidence of the use of Google Maps to aid crime location choice has been documented, but its prevalence is not known (Vandeviver, 2014).
}

either measured small subsets of activity nodes using large administrative datasets, or measured all activity nodes in small survey samples, which precluded comparison of different node types. Future studies could explore 'big data' sources (such as those used by the human mobility studies cited here), expand survey samples, identify additional administrative data on activity nodes (e.g., Authors, under review), and innovate using existing offender location-monitoring data (e.g., Rossmo et al., 2012). Each data source provides potential to operationalise variables in this framework, perhaps partially in isolation, but painting a fuller picture when combined. DSCM involves assumptions, such as decision-makers considering all choice alternatives and deciding based on utility maximisation, which some argue are not applicable to all location choices (Arentze \& Timmermans, 2005; Golledge \& Stimson, 1997; Hannes et al., 2012; Ruiter, 2017). As with any theory building endeavour, its predictions need to be robust to testing via a range of methods.

\section{Conclusion}

This paper has presented a systematic framework within which to consider the causal relations between activity nodes, opportunity, and crime location choice. It contributes to the ongoing elaboration of environmental criminology theories. But its contribution is more than theoretical. From a practical perspective, the framework enables predictions about which of an offender's prior activity nodes is more likely to be near a given offence. Such predictions can be used in the context of geographic profiling (Knabe-Nichol \& Alison, 2011; Rossmo, 2000, 2014) in police investigations. For example, identifying which prior activity nodes may be more salient to a given crime can inform the prioritisation of suspects, given knowledge of their different activity nodes. Understanding the relative influence of different activity nodes can also help in formulating sentenced offenders' supervision conditions and risk management planning, by identifying places of higher risk for individual offenders, which should be avoided. For example, offenders on electronic monitoring might be restricted from entering areas identified as likely offending locations based on their prior activities there. Of further significance, since crime location choice exemplifies general location choice processes, this framework has potential wider application to noncriminal behaviour studied in the fields of human mobility and urban planning.

\section{Acknowledgements}

We are grateful to all reviewers who provided feedback on earlier versions of this paper, which helped to refine our ideas and improve the manuscript. 


\section{Authors' contributions}

SCH developed the theoretical framework and drafted and revised the manuscript. WB, OM and DP reviewed and provided feedback on all drafts of the manuscript. All authors read and approved the final manuscript.

\section{Funding}

This research forms part of the first author's PhD thesis, which is funded by a University of Waikato doctoral scholarship.

\section{Availability of data and materials}

Not applicable.

\section{Ethics approval and consent to participate}

Not applicable.

\section{Consent for publication}

Not applicable.

\section{Competing interests}

The authors declare that they have no competing interests.

\section{Author details}

${ }^{1}$ Institute of Security and Crime Science and School of Psychology, University of Waikato, Knighton Road, Hamilton 3240, New Zealand. ${ }^{2}$ Netherlands Institute for the Study of Crime and Law Enforcement (NSCR), Amsterdam, The Netherlands. ${ }^{3}$ School of Business and Economics, Department of Spatial Economics, Vrije Universiteit Amsterdam, Amsterdam, The Netherlands.

Received: 24 June 2020 Accepted: 18 October 2020 Published online: 04 November 2020

\section{References}

Ackerman, J. M., \& Rossmo, D. K. (2015). How far to travel? A multilevel analysis of the residence-to-crime distance. Journal of Quantitative Criminology, 31(2), 237-262. https://doi.org/10.1007/s10940-014-9232-7.

Alessandretti, L., Sapiezynski, P., Sekara, V., Lehmann, S., \& Baronchelli, A. (2018). Evidence for a conserved quantity in human mobility. Nature Human Behaviour, 2(7), 485-491. https://doi.org/10.1038/s41562-018-0364-x.

Arentze, T. A., Dellaert, B. G. C., \&Timmermans, H. J. P. (2008). Modeling and measuring individuals' mental representations of complex spatiotemporal decision problems. Environment and Behavior, 40(6), 843-869. https://doi.org/10.1177/0013916507309994.

Arentze, T. A., \& Timmermans, H. J. P. (2005). Representing mental maps and cognitive learning in micro-simulation models of activity-travel choice dynamics. Transportation, 32(4), 321-340. https://doi.org/10.1007/s1111 6-004-7964-1.

Banerjee, A., Duflo, E., Keniston, D., \& Singh, N. (2019). The efficient deployment of police resources: Theory and new evidence from a randomized drunk driving crackdown in India (No. w26224). Cambridge, MA : National Bureau of Economic Research. https://doi.org/10.3386/w26224.

Barbosa, H., de Lima-Neto, F., Evsukoff, A., \& Menezes, R. (2015). The effect of recency to human mobility. EPJ Data Science, 4(1), 1-14. https://doi. org/10.1140/epjds/s13688-015-0059-8.

Ben-Akiva, M. E., \& Bowman, J. L. (2016). Integration of an activity-based model system and a residential location model. Urban Studies. https://doi. org/10.1080/0042098984529.

Ben-Akiva, M. E., \& Lerman, S. R. (1985). Discrete choice analysis: Theory and application to travel demand. Cambridge, MA: MIT Press.

Bernasco, W. (2006). Co-offending and the choice of target areas in burglary. Journal of Investigative Psychology and Offender Profiling, 3(3), 139-155. https://doi.org/10.1002/jip.49.

Bernasco, W. (2008). Them again?: Same-offender involvement in repeat and near repeat burglaries. European Journal of Criminology, 5(4), 411-431. https://doi.org/10.1177/1477370808095124.

Bernasco, W. (2010). A sentimental journey to crime: Effects of residential history on crime location choice. Criminology, 48(2), 389-416. https://doi. org/10.1111/j.1745-9125.2010.00190.x.
Bernasco, W. (2018). Mobility and location choice of offenders. In G. J. N. Bruinsma \& S. D. Johnson (Eds.), The Oxford handbook of environmental criminology. Oxford: Oxford University Press. https://doi.org/10.1093/ oxfordhb/9780190279707.001.0001/oxfordhb-9780190279707-e-17

Bernasco, W. (2019). Adolescent offenders'current whereabouts predict locations of their future crimes. PLOS ONE, 14(1), e0210733. https://doi. org/10.1371/journal.pone.0210733.

Bernasco, W., \& van Dijke, R. (2020). Do offenders avoid offending near home? A systematic review of the buffer zone hypothesis. Crime Science, 9(1), 1-10. https://doi.org/10.1186/s40163-020-00118-5.

Bernasco, W., Johnson, S. D., \& Ruiter, S. (2015). Learning where to offend: Effects of past on future burglary locations. Applied Geography, 60(Supplement C), 120-129. https://doi.org/10.1016/j.apgeog.2015.03.014.

Bernasco, W., \& Kooistra, T. (2010). Effects of residential history on commercial robbers' crime location choices. European Journal of Criminology, 7(4), 251-265. https://doi.org/10.1177/1477370810363372.

Bernasco, W., Ruiter, S., Bruinsma, G. J. N., Pauwels, L. J. R., \&Weerman, F. M. (2013). Situational causes of offending: A fixed-effects analysis of space-time budget data. Criminology, 51(4), 895-926. https://doi. org/10.1111/1745-9125.12023.

Bichler, G., Christie-Merrall, J., \& Sechrest, D. (2011). Examining juvenile delinquency within activity space: Building a context for offender travel patterns. Journal of Research in Crime and Delinquency, 48(3), 472-506. https://doi.org/10.1177/0022427810393014.

Bichler, G., Malm, A., \& Christie-Merrall, J. (2012). Urban backcloth and regional mobility patterns as indicators of juvenile crime. In M. A. Andresen \& J. B. Kinney (Eds.), Patterns, prevention, and geometry of crime (pp. 118-136). London, UK: Routledge.

Bichler, G., Malm, A., \& Enriquez, J. (2014). Magnetic facilities: Identifying the convergence settings of juvenile delinquents. Crime and Delinquency, 60(7), 971-998. https://doi.org/10.1177/0011128710382349.

Bichler, G., Schwartz, J. A., \& Orosco, C. A. (2010). Delinquents on the move: Examining subgroup travel variability. Crime Patterns and Analysis, 3(1), 14-37.

Brantingham, P. J., \& Tita, G. (2008). Offender mobility and crime pattern formation from first principles. In L. Liu \& J. Eck (Eds.), Artificial crime analysis systems: Using computer simulations and geographic information systems (pp. 193-208). Pennsylvania: IGl Global.

Brantingham, P. L., \& Brantingham, P. J. (1991). Notes on the geometry of crime. In P. J. Brantingham \& P. L. Brantingham (Eds.), Environmental criminology (2nd ed., pp. 27-54). Long Grove: Waveland Press.

Brantingham, P. L., \& Brantingham, P. J. (1993). Environment, routine, and situation: Toward a pattern theory of crime. In R. V. Clarke \& M. Felson (Eds.), Routine activity and rational choice (pp. 259-294). Piscataway, NJ: Transaction Publishers.

Brantingham, P. L., \& Brantingham, P. J. (1995). Criminality of place: Crime generators and crime attractors. European Journal on Criminal Policy and Research, 3(3), 5-26. https://doi.org/10.1007/BF02242925.

Brantingham, P. J., \& Brantingham, P. L. (2012). The theory of target search. In F. T. Cullen \& P. Wilcox (Eds.), The Oxford Handbook of Criminological Theory. Oxford: Oxford University Press. https://doi.org/10.1093/oxfor dhb/9780199747238.013.0028.

Brantingham, P. J., Brantingham, P. L., \& Andresen, M. A. (2008). The geometry of crime and crime pattern theory. In R. Wortley \& M. Townsley (Eds.), Environmental Criminology and Crime Analysis (pp. 98-117). Milton Park: Taylor and Francis.

Brown, L. A., \& Moore, E. G. (1970). The intra-urban migration process: A perspective. Geografiska Annaler Series B, Human Geography, 52(1), 1-13. https://doi.org/10.2307/490436.

Canter, D., \& Larkin, P. (2008). The environmental range of serial rapists. In D. Canter \& D. Youngs (Eds.), Applications of geographical offender profiling (pp. 57-68). Farnham, UK: Ashgate.

Chorus, C. G., \&Timmermans, H. J. P. (2010). Determinants of stated and revealed mental map quality: An empirical study. Journal of Urban Design, 15(2), 211-226. https://doi.org/10.1080/13574801003638095.

Clare, J. (2011). Examination of systematic variations in burglars' domain-specific perceptual and procedural skills. Psychology, Crime and Law, 17(3), 199-214. https://doi.org/10.1080/10683160903025810.

Clarke, R. V., \& Cornish, D. B. (1985). Modeling offenders' decisions: A framework for research and policy. Crime and Justice, 6, 147-185. 
Cornish, D. B., \& Clarke, R. V. (1986). The reasoning criminal: Rational choice perspectives on offending. Berlin: Springer-Verlag.

Costello, A., \& Wiles, P. (2001). GIS and the journey to crime: An analysis of patterns in South Yorkshire. In K. J. Bowers \& A. Hirschfield (Eds.), Mapping and analysing crime data: Lessons from research and practice (pp. 27-60). Milton Park: Taylor and Francis.

Cromwell, P. F., Olson, J. N., \& Avary, D. W. (1990). Breaking and entering: An ethnographic analysis of burglary (1st ed.). Newbury Park, CA: Sage.

Downs, R. M., \& Stea, D. (1973). Cognitive maps and spatial behavior: Process and products. In R. M. Downs \& D. Stea (Eds.), Image and environment: Cognitive mapping and spatial behavior (pp. 8-26). Aldine, CA: Aldine.

Elffers, H. (2004). Decision models underlying the journey to crime. In G. J. N. Bruinsma, H. Elffers, \& J. W. De Keijser (Eds.), Punishment, places and perpetrators: Developments in criminology and criminal justice research (pp. 182-197). London: Willan.

Felson, M. (2008). The routine activity approach. In R. Wortley \& L. Mazerolle (Eds.), Environmental criminology and crime analysis (pp. 87-97). London: Willan.

Frith, M. J. (2019). Modelling taste heterogeneity regarding offence location choices. Journal of Choice Modelling, 33, 100187. https://doi. org/10.1016/j.jocm.2019.100187.

Frith, M. J., Johnson, S. D., \& Fry, H. M. (2017). Role of the street network in burglars' spatial decision-making. Criminology, 55(2), 344-376. https:// doi.org/10.1111/1745-9125.12133.

Gärling, T., \& Axhausen, K. W. (2003). Introduction: Habitual travel choice. Transportation, 30(1), 1-11. https://doi.org/10.1023/A:1021230223 001.

Gentner, D., \& Medina, J. (1998). Similarity and the development of rules. Cognition, 65(2), 263-297. https://doi.org/10.1016/S0010 -0277(98)00002-X.

Golledge, R. (1978). Representing, interpreting and using cognized environments. Papers in Regional Science, 41(1), 169-204. https://doi. org/10.1111/j.1435-5597.1978.tb01046.x.

Golledge, R. (1999). Human wayfinding and cognitive maps. In R. Golledge (Ed.), Wayfinding behavior: Cognitive mapping and other spatial processes (pp. 5-45). Baltimore: Johns Hopkins University Press.

Golledge, R., \& Stimson, R. (1997). Spatial behavior: A geographic perspective. New York, NY: Guilford Press.

González, M. C., Hidalgo, C. A., \& Barabási, A.-L. (2008). Understanding individual human mobility patterns. Nature, 453(7196), 779-782. https://doi. org/10.1038/nature06958.

Gould, P. (1966). On mental maps. Ann Arbor, MI: University of Michigan.

Gould, P. (1973). On mental maps. In R. M. Downs \& D. Stea (Eds.), Image and environment: Cognitive maps and spatial behavior (pp. 182-220). Aldine, CA: Aldine.

Gould, P., \&White, R. (1986). Mental maps (2nd ed.). London: Routledge.

Hammond, L., \& Youngs, D. (2011). Decay functions and criminal spatial processes: Geographical offender profiling of volume crime. Journal of Investigative Psychology and Offender Profiling, 8(1), 90-102. https://doi. org/10.1002/jip.132.

Hannes, E., Janssens, D., and Wets, G. (2006, August). Proximity is a state of mind: Exploring mental maps in daily activity travel behaviour. 11th International Conference on Travel Behaviour Research, Kyoto.

Hannes, E., Janssens, D., \&Wets, G. (2008). Destination choice in daily activity travel: Mental map's repertoire. Transportation Research Record, 2054(1), 20-27. https://doi.org/10.3141/2054-03.

Hannes, E., Janssens, D., \&Wets, G. (2009). Does space matter? Travel mode scripts in daily activity travel. Environment and Behavior, 41(1), 75-100. https://doi.org/10.1177/0013916507311033.

Hannes, E., Kusumastuti, D., Espinosa, M., Janssens, D., Vanhoof, K., \& Wets, G. (2012). Mental maps and travel behaviour: Meanings and models. Journal of Geographical Systems, 14(2), 143-165. https://doi.org/10.1007/ s10109-010-0144-2.

Hanson, S., \& Huff, O. J. (1988). Systematic variability in repetitious travel. Transportation, 15(1), 111-135. https://doi.org/10.1007/BF00167983.

Hasan, S., Schneider, C. M., Ukkusuri, S. V., \& González, M. C. (2013). Spatiotemporal patterns of urban human mobility. Journal of Statistical Physics, 151(1), 304-318. https://doi.org/10.1007/s10955-012-0645-0.

Hillier, A., Smith, T. E., Whiteman, E. D., \& Chrisinger, B. W. (2017). Discrete choice model of food store trips using National Household Food Acquisition and Purchase Survey (FoodAPS). International Journal of Environmental Research and Public Health. https://doi.org/10.3390/ijerph14101133.

Horton, F. E., \& Reynolds, D. R. (1971). Effects of urban spatial structure on individual behavior. Economic Geography, 47(1), 36-48. https://doi. org/10.2307/143224

Howard, R. W. (2000). Generalization and transfer: An interrelation of paradigms and a taxonomy of knowledge extension processes. Review of General Psychology, 4(3), 211-237. https://doi.org/10.1037/1089-2680.4.3.211.

Ida, T., \& Kuroda, T. (2006). Discrete choice analysis of demand for broadband in japan. Journal of Regulatory Economics, 29(1), 5-22. https://doi. org/10.1007/s11149-005-5124-y.

Johnson, S. D., \& Bowers, K. J. (2004). The stability of space-time clusters of burglary. The British Journal of Criminology, 44(1), 55-65. https://doi. org/10.1093/bjc/44.1.55.

Johnson, S. D., Summers, L., \& Pease, K. (2009). Offender as forager? A direct test of the boost account of victimization. Journal of Quantitative Criminology, 25(2), 181-200. https://doi.org/10.1007/s10940-008-9060-8.

Kahneman, D. (2003). Maps of bounded rationality: Psychology for behavioral economics. American Economic Review, 93(5), 1449-1475. https://doi. org/10.1257/000282803322655392.

Kang, C., Ma, X., Tong, D., \& Liu, Y. (2012). Intra-urban human mobility patterns: An urban morphology perspective. Physica A: Statistical Mechanics and Its Applications, 391(4), 1702-1717. https://doi.org/10.1016/j.physa .2011.11.005.

Knabe-Nichol, S., \& Alison, L. (2011). The cognitive expertise of Geographic Profilers. In L. Alison \& L. Rainbow (Eds.), Professionalizing offender profiling: Forensic and investigative psychology in practice (pp. 126-159). Milton Park: Taylor and Francis.

Kuang, D., Brantingham, P. J., \& Bertozzi, A. (2017). Crime topic modeling. Crime Science, 6(1), 1-20. https://doi.org/10.1186/s40163-017-0074-0.

Lammers, M. (2018). Co-offenders' crime location choice: Do co-offending groups commit crimes in their shared awareness space? The British Journal of Criminology, 58, 1193-1211. https://doi.org/10.1093/bjc/azx069.

Lammers, M., Menting, B., Ruiter, S., \& Bernasco, W. (2015). Biting once, twice: The influence of prior on subsequent crime location choice. Criminology, 53(3), 309-329. https://doi.org/10.1111/1745-9125.12071.

Lantz, B., \& Ruback, R. B. (2017). A networked boost: Burglary co-offending and repeat victimization using a network approach. Crime and Delinquency, 63(9), 1066-1090. https://doi.org/10.1177/0011128715597695.

Lattimore, P., \& Witte, A. (1986). Models of decision making under uncertainty: The criminal choice. In D. B. Cornish \& R. V. Clarke (Eds.), The reasoning criminal (pp. 129-155). Berlin: Springer-Verlag. https://doi. org/10.4324/9781315134482-2.

Lloyd, R., \& Cammack, R. (1996). Constructing cognitive maps with orientation biases. In J. Portugali (Ed.), The construction of cognitive maps (pp. 187-213). Netherlands: Springer. https://doi.org/10.1007/978-0-58533485-1_9.

Long, D., Liu, L., Feng, J., \& Zhou, S. (2018). Assessing the influence of prior on subsequent street robbery location choices: A case study in ZG city China. Sustainability, 10(6), 1818. https://doi.org/10.3390/su10061818.

Mark, D. M., Freksa, C., Hirtle, S. C., Lloyd, R., \& Tversky, B. (1999). Cognitive models of geographical space. International Journal of Geographical Information Science, 13, 747-774. https://doi.org/10.1080/136588199241003.

McDaniel, M. A., Cahill, M. J., Robbins, M., \&Wiener, C. (2014). Individual differences in learning and transfer: Stable tendencies for learning exemplars versus abstracting rules. Journal of Experimental Psychology: General, 143(2), 668-693. https://doi.org/10.1037/a0032963.

McFadden, D. L. (1984). Econometric analysis of qualitative response models. In P. Griliches \& M. D. Intriligator (Eds.), Handbook of econometrics (Vol. 2, pp. 105-142). Amsterdam: Elsevier. https://doi.org/10.1016/S1573 $-4412(84) 02016-X$.

Menting, B. (2018). Awareness $x$ opportunity: Testing interactions between activity nodes and criminal opportunity in predicting crime location choice. The British Journal of Criminology, 58, 1171-1192. https://doi. org/10.1093/bjc/azx049.

Menting, B., Lammers, M., Ruiter, S., \& Bernasco, W. (2016). Family matters: Effects of family members' residential areas on crime location choice. Criminology, 54(3), 413-433. https://doi.org/10.1111/1745-9125.12109.

Menting, B., Lammers, M., Ruiter, S., \& Bernasco, W. (2020). The influence of activity space and visiting frequency on crime location choice: Findings 
from an online self-report survey. The British Journal of Criminology, 60(2), 303-322. https://doi.org/10.1093/bjc/azz044.

Miller, J. (2013). Individual offending, routine activities, and activity settings: Revisiting the routine activity theory of general deviance. Journal of Research in Crime and Delinquency, 50(3), 390-416. https://doi. org/10.1177/0022427811432641.

Nee, C. (2015). Understanding expertise in burglars: From pre-conscious scanning to action and beyond. Aggression and Violent Behavior, 20(Supplement C), 53-61. https://doi.org/10.1016/j.avb.2014.12.006.

Nee, C., \& Meenaghan, A. (2006). Expert decision making in burglars. The British Journal of Criminology, 46(5), 935-949. https://doi.org/10.1093/ bjc/azl013.

Nevo, A. (2001). Measuring market power in the ready-to-eat cereal industry. Econometrica, 69(2), 307-342.

Nguyen, H. T. A., Chikaraishi, M., Fujiwara, A., \& Zhang, J. (2017). Mediation effects of income on travel mode choice: Analysis of short-distance trips based on path analysis with multiple discrete outcomes. Transportation Research Record, 2664(1), 23-30. https://doi. org/10.3141/2664-03.

Pappalardo, L., Simini, F., Rinzivillo, S., Pedreschi, D., Giannotti, F., \& Barabási, A.-L. (2015). Returners and explorers dichotomy in human mobility. Nature Communications, 6, 8166-8173. https://doi.org/10.1038/ ncomms9166.

Pease, K. (1998). Repeat victimisation: Taking stock. London: Home Office.

Ratcliffe, J. H. (2006). A temporal constraint theory to explain opportunitybased spatial offending patterns. Journal of Research in Crime and Delinquency, 43(3), 261-291. https://doi.org/10.1177/0022427806286566.

Reid, A. A., Frank, R., Iwanski, N., Dabbaghian, V., \& Brantingham, P. L. (2014). Uncovering the spatial patterning of crimes: A criminal movement model (CRiMM). Journal of Research in Crime and Delinquency, 51(2), 230-255. https://doi.org/10.1177/0022427813483753.

Rengert, G. (1996). The geography of illegal drugs. Boulder: Westview Press.

Rengert, G., \& Wasilchick, J. (1985). Suburban burglary: A time and a place for everything. Springfield: C.C Thomas.

Rengert, G., \& Wasilchick, J. (2000). Suburban burglary: A tale of two suburbs (2nd ed.). Springfield: C.C Thomas.

Rossmo, D. K. (2000). Geographic profiling. Boca Raton, FL: CRC Press.

Rossmo, D. K. (2014). Geographic profiling. In G. J. N. Bruinsma \& D. Weisburd (Eds.), Encyclopedia of criminology and criminal justice (pp. 1934-1942). Berlin: Springer.

Rossmo, D. K., Lu, Y., \& Fang, T. B. (2012). Spatial-temporal crime paths. In M. A. Andresen \& J. B. Kinney (Eds.), Patterns, prevention, and geometry of crime (pp. 3-15). London: Routledge.

Ruiter, S. (2017). Crime location choice. In W. Bernasco, J.-L. Van Gelder, \& H. Elffers (Eds.), The Oxford handbook of offender decision making (pp. 398-420). Oxford: Oxford University Press.

Ruiter, S., and Davies, T. (2018, July). BTW, a test of crime pattern theory. Environmental Criminology and Crime Analysis Symposium, Spain.

Sivakumar, A., \& Bhat, C. R. (2007). A comprehensive, unified framework for analyzing spatial location choice. Transportation Research Record, 2003(1), 103-111. https://doi.org/10.3141/2003-13.

Smith, W., Bond, J. W., \& Townsley, M. (2009). Determining how journeys-tocrime vary: Measuring inter- and intra-offender crime trip distributions. In D. Weisburd, W. Bernasco, \& G. J. N. Bruinsma (Eds.), Putting crime in its place (pp. 217-236). Berlin: Springer.

Song, C., Qu, Z., Blumm, N., \& Barabási, A.-L. (2010). Limits of predictability in human mobility. Science, 327(5968), 1018-1021. https://doi. org/10.1126/science.1177170.

Sorg, E. T., Haberman, C. P., Ratcliffe, J. H., \& Groff, E. R. (2013). Foot patrol in violent crime hot spots: The longitudinal impact of deterrence and posttreatment effects of displacement. Criminology, 51(1), 65-101. https://doi.org/10.1111/j.1745-9125.2012.00290.x.

Summers, L., Johnson, S. D., \& Rengert, G. (2010). The use of maps in offender interviewing. In W. Bernasco (Ed.), Offenders on offending: Learning about crime from criminals (pp. 246-272). London: Willan.

Tenenbaum, J. B., \& Griffiths, T. L. (2001). Generalization, similarity, and Bayesian inference. Behavioral and Brain Sciences, 24(4), 629-640. https:// doi.org/10.1017/S0140525X01000061.

Tillyer, M. S., \& Walter, R. J. (2019). Busy businesses and busy contexts: The distribution and sources of crime at commercial properties. Journal of Research in Crime and Delinquency, 56(6), 816-850. https://doi. org/10.1177/0022427819848083..

Tobler, W. R. (1970). A computer movie simulating urban growth in the Detroit region. Economic Geography, 46, 234-240. https://doi. org/10.2307/143141.

Tolman, E. C. (1948). Cognitive maps in rats and men. Psychological Review, 55(4), 189-208. https://doi.org/10.1037/h0061626.

Tonkin, M., Santtila, P., \& Bull, R. (2012). The linking of burglary crimes using offender behaviour: Testing research cross-nationally and exploring methodology. Legal and Criminological Psychology, 17(2), 276-293. https://doi.org/10.1111/j.2044-8333.2010.02007.x.

Tonkin, M., Woodhams, J., Bull, R., Bond, J. W., \& Palmer, E. J. (2011). Linking different types of crime using geographical and temporal proximity. Criminal Justice and Behavior, 38(11), 1069-1088. https://doi. org/10.1177/0093854811418599.

Toole, J. L., Herrera-Yaqüe, C., Schneider, C. M., \& González, M. C. (2015). Coupling human mobility and social ties. Journal of the Royal Society Interface, 12(105), 20141128-20141128. https://doi.org/10.1098/ rsif.2014.1128.

Townsley, M. (2016). Offender mobility. In R. Wortley \& M. Townsley (Eds.), Environmental criminology and crime analysis (pp. 142-161). London: Routledge.

Townsley, M., Birks, D., Ruiter, S., Bernasco, W., \& White, G. (2016). Target selection models with preference variation between offenders. Journal of Quantitative Criminology, 32(2), 283-304. https://doi. org/10.1007/s10940-015-9264-7.

van Daele, S., \& Vander Beken, T. (2011). Out of sight, out of mind? Awareness space and mobile offenders. European Journal of Crime, Criminal Law and Criminal Justice, 19(2), 125-137. https://doi. org/10.1163/157181711X566326.

van Daele, S., Vander Beken, T., \& Bruinsma, G. J. N. (2012). Does the mobility of foreign offenders fit the general pattern of mobility? European Journal of Criminology, 9(3), 290-308. https://doi.org/10.1177/14773 70812440065.

van Sleeuwen, S. E. M., Ruiter, S., \& Menting, B. (2018). A time for a crime: Temporal aspects of repeat offenders' crime location choices. Journal of Research in Crime and Delinquency, 55(4), 538-568. https://doi. org/10.1177/0022427818766395.

Vandeviver, C. (2014). Applying Google Maps and Google Street View in criminological research. Crime Science, 3(1), 13. https://doi. org/10.1186/s40163-014-0013-2.

Vandeviver, C., \& Bernasco, W. (2019). "Location, location, location": Effects of neighborhood and house attributes on burglars'target selection. Journal of Quantitative Criminology. https://doi.org/10.1007/s1094 0-019-09431-y.

Wang, J., Dong, L., Cheng, X., Yang, W., \& Liu, Y. (2019). An extended exploration and preferential return model for human mobility simulation at individual and collective levels. Physica A: Statistical Mechanics and Its Applications, 534, 121921. https://doi.org/10.1016/j.physa.2019.12192 1.

Ward, T., Polaschek, D. L. L., \& Beech, A. R. (2005). Theory construction, development and evaluation. Theories of sexual offending (pp. 3-16). Hoboken: Wiley. https://doi.org/10.1002/9780470713648.ch1.

Weisburd, D., Eck, J. E., Braga, A. A., Telep, C. W., Cave, B., Bowers, K., et al. (2016). Place matters: Criminology for the twenty-first century. Cambridge University Press. https://doi.org/10.1017/CBO9781139342087.

Wikström, P.-O., Ceccato, V., Hardie, B., \& Treiber, K. (2010). Activity fields and the dynamics of crime. Journal of Quantitative Criminology, 26(1), 55-87. https://doi.org/10.1007/s10940-009-9083-9.

Wiles, P., \& Costello, A. (2008). The 'road to nowhere': The evidence for travelling criminals. In D. Canter \& D. Youngs (Eds.), Principles of geographical offender profiling (pp. 165-175). Farnham: Ashgate.

Wolpert, J. (1965). Behavioral aspects of the decision to migrate. Papers in Regional Science, 15(1), 159-169. https://doi. org/10.1111/j.1435-5597.1965.tb01320.x.

Wright, R., \& Decker, S. H. (1994). Burglars on the job: Streetlife and residential break-ins. Boston, MA: Northeastern University Press.

Xiao, L., Liu, L., Song, G., Ruiter, S., \& Zhou, S. (2018). Journey-to-crime distances of residential burglars in China disentangled: Origin and destination effects. ISPRS International Journal of Geo-Information, 7(8), 325. https://doi.org/10.3390/ijgi7080325. 
Yan, X.-Y., Wang, W.-X., Gao, Z.-Y., \& Lai, Y.-C. (2017). Universal model of individual and population mobility on diverse spatial scales. Nature Communications, 8(1), 1-9. https://doi.org/10.1038/s41467-01701892-8.

Zhang, W., Ahmad Termida, N., \& Susilo, Y. O. (2019). What construct one's familiar area? A quantitative and longitudinal study. Environment and Planning B: Urban Analytics and City Science, 46(2), 322-340. https:// doi.org/10.1177/2399808317714798.
Zhang, W., Susilo, Y. O., \& Ahmad Termida, N. (2016). Investigating the interactions between travellers' familiar areas and their multi-day activity locations. Journal of Transport Geography, 53, 61-73. https://doi. org/10.1016/j.jtrangeo.2016.04.012.

\section{Publisher's Note}

Springer Nature remains neutral with regard to jurisdictional claims in published maps and institutional affiliations.
Ready to submit your research? Choose BMC and benefit from:

- fast, convenient online submission

- thorough peer review by experienced researchers in your field

- rapid publication on acceptance

- support for research data, including large and complex data types

- gold Open Access which fosters wider collaboration and increased citations

- maximum visibility for your research: over 100M website views per year

At BMC, research is always in progress.

Learn more biomedcentral.com/submissions 